\title{
Fighting the Good Fight: The Janitor's Strike at the University of Miami
}

\author{
Christian A.I. Schlaerth ${ }^{*}$ \\ John W. Murphy ${ }^{\dagger}$
}

This paper is a case study regarding a janitors' strike that occurred at the University of Miami during the spring semester of 2006. It discusses the various tactics that the University used in order to discourage the workers from organizing a labor union in a manner that they chose, i.e. the card check method. Many of the maneuvers and strategies used by the University resemble those that are used by corporations to prevent labor organization. This leads to the conclusion that many universities and colleges are being run more like businesses than schools, and that a partnership must be formed between students and faculty in order to take back the institutions of higher education. [Article copies available for a fee from The Transformative Studies Institute. E-mail address: journal@transformativestudies.org Website: http://www.transformativestudies.org (C2009 by The Transformative Studies Institute. All rights reserved.]

KEYWORDS: Student Movements, Social Change, Strikes, Higher Education.

\footnotetext{
* Christian A.I. Schlaerth, University of Miami. Christian received his BA from LeMoyne College. He is currently a graduate student in sociology at the University of Miami, where he received his MA. His research interests include social theory, social psychology, and racial oppression. Address correspondence to: Christian A.I. Schlaerth, Department of Sociology, University of Miami, Merrick Building 120, 5202 University Dr., Coral Gables, FL 33146; e-mail: cschlaerth@miami.edu.

$\dagger$ John W. Murphy, Ph.D., University of Miami. John is a professor of sociology at the University of Miami. He received his BA from Kent State University, MA from Ohio University, and his $\mathrm{PhD}$ from Ohio State University. His research interests include social philosophy and globalization. Address correspondence to: John W. Murphy, Department of Sociology, University of Miami, Merrick Building 120, 5202 University Dr., Coral Gables, FL 33146; e-mail: j.murphy@miami.edu.
} 